\title{
The Decline of Activist Stabilization Policy: Natural Rate Misperceptions, Learning, and Expectations
}

\author{
Athanasios Orphanides \\ Board of Governors of the Federal Reserve System \\ and \\ John C. Williams* \\ Federal Reserve Bank of San Francisco
}

December 2003

\begin{abstract}
We develop an estimated model of the U.S. economy in which agents form expectations by continually updating their beliefs regarding the behavior of the economy and monetary policy. We explore the effects of policymakers' misperceptions of the natural rate of unemployment during the late 1960s and 1970s on the formation of expectations and macroeconomic outcomes. We find that the combination of monetary policy directed at tight stabilization of unemployment near its perceived natural rate and large real-time errors in estimates of the natural rate uprooted heretofore quiescent inflation expectations and destabilized the economy. Had monetary policy reacted less aggressively to perceived unemployment gaps, inflation expectations would have remained anchored and the stagflation of the 1970s would have been avoided. Indeed, we find that less activist policies would have been more effective at stabilizing both inflation and unemployment. We argue that policymakers, learning from the experience of the 1970s, eschewed activist policies in favor of policies that concentrated on the achievement of price stability, contributing to the subsequent improvements in macroeconomic performance of the U.S. economy.
\end{abstract}

KEYWORDS: Monetary policy, stagflation, rational expectations, learning.

JEL Classification System: E52

Correspondence: Orphanides: Federal Reserve Board, Washington, D.C. 20551, Tel.: (202) 452-2654, e-mail: Athanasios.Orphanides@frb.gov. Williams: Federal Reserve Bank of San Francisco, 101 Market Street, San Francisco, CA 94105, Tel.: (415) 974-2240, e-mail: John.C.Williams@sf.frb.org. ${ }^{*}$ We would like to thank Alex Cukierman, Vitor Gaspar, Glenn Rudebusch, Robert Solow, and participants at presentations at Georgetown University, the Workshop on Expectations, Learning and Monetary Policy, Eltville, August 30-31, 2003, and the International Research Forum on Monetary Policy, Washington, D.C., November, 14-15, 2003, for useful comments and discussions on earlier drafts. Kirk Moore provided excellent research assistance. The opinions expressed are those of the authors and do not necessarily reflect views of the Board of Governors of the Federal Reserve System or the management of the Federal Reserve Bank of San Francisco. 


\section{Introduction}

The "New Economics" of the 1960s prescribed activist policies aimed at achieving and maintaining full employment of economic resources. According to this view, active management of aggregate demand would counteract any shortfalls or excesses relative to the economy's potential and thus attain the holy grail of macroeconomic policy: sustained prosperity with price stability. This faith in macroeconomic stabilization policy reflected the culmination of methodological advances in macroeconomic modeling, econometrics, and optimal control. ${ }^{1}$ The zeitgeist of the "New Economics" is nicely summarized by Walter Heller (1966):

The promise of modern economic policy, managed with an eye to maintaining prosperity, subduing inflation, and raising the quality of life, is indeed great. And although we have made no startling conceptual breakthroughs in economics in recent years, we have, more effectively than ever before, harnessed the existing economics - the economics that has been taught in the nation's college classrooms for some twenty years - to the purposes of prosperity, stability, and growth. (page 116, emphasis in original.)

The enviable performance of the U.S. economy in the first half of the 1960s appeared to validate the claims of Heller, but this success proved to be fleeting. In the second half of the 1960s, prosperity was purchased at the cost of rising inflation, as seen in Figure 1. Worse, the prosperity of the 1960s was soon overshadowed by the stagflation-high inflation accompanied by high unemployment-in the 1970s.

In this paper, we reexamine the sources of stagflation in the 1970s, and argue that the combination of monetary policy directed at tight stabilization of the unemployment rate near its perceived natural rate and severe underestimation of the natural rate, rather than adverse supply shocks, explains much of the woeful performance of the U.S. economy in the 1970s. With hindsight, it is clear that policymakers in the 1960s and much of the 1970s were far too optimistic of how low the unemployment rate could go before igniting inflation pressures. Given the activist bent of policymakers influenced by the "New Economics," these natural rate misperceptions contributed to an extended period of policy being excessively stimulative, resulting in rising inflation. ${ }^{2}$

\footnotetext{
${ }^{1}$ See Heller (1966), Tobin $(1966,1972)$ and Okun (1970) for discussions of the ideas associated with the "New Economics" of the 1960s. Application of control methods for macroeconomic stabilization had been discussed at least as early as Lerner (1944) and formalized by Phillips (1954). Friedman's (1947) review of Lerner (1944) offers an early critique of the application of these methods for macroeconomic stabilization.

${ }^{2}$ See Orphanides (2002, 2003a,b, forthcoming), Orphanides and Williams (2002), Bullard and Eusepi (2003), Collard and Dellas (2003), and Cukierman and Lippi (2003).
} 
A key element in our analysis is the endogenous evolution of expectations formation in response to the tumultuous economic developments of the late 1960s and 1970s. We develop an estimated model of the U.S. economy in which private agents have imperfect knowledge of the true structure of the economy and policy. In the model, agents are assumed to continuously update their beliefs about the reduced-form structure of the economy and monetary policy. As discussed in Orphanides and Williams (2003, forthcoming), this process of perpetual learning propagates the direct effects of policy errors onto inflation expectations and back on the economy.

According to our model, the combination of stimulative monetary policy and rising inflation during the late 1960s and 1970s contributed to private agent confusion regarding the Federal Reserve's objectives and the behavior of inflation. Although inflation expectations were initially well-anchored owing to the period of price stability in the 1950s and early 1960 s, this advantage was squandered during the late 1960s as policy errors and the resulting rise in inflation caused inflation expectations to drift upward. ${ }^{3}$ By the time that the supply shocks of the 1970s hit, inflation expectations were already unmoored, exacerbating the response to the shocks and contributing to stagflation. It is worth noting that our results do not rely on policy being inherently destabilizing in the pre-1979 period, as emphasized by Clarida, Gali, and Gertler (2000). In fact, the feedback rule that we estimate for the pre-1979 period based on real-time data features a greater than one-for-one response of nominal rates to inflation. What is crucial for our results is that policy responded strongly to perceived unemployment rate gaps during that period as indicated by our estimated policy feedback rule.

We find that had monetary policy not reacted as aggressively to perceived unemployment gaps as it did, inflation expectations would have remained anchored and the stagflation of the 1970s would have been avoided, despite the dramatic increases in oil prices and the productivity slowdown during that period. Importantly, according to our model, less activist policies would have done a better job of stabilizing both inflation and unemployment in the 1970s. This is a lesson that policymakers themselves appeared to recognize by end

\footnotetext{
${ }^{3}$ The favorable environment of inflation expectations in the early 1960 s can be largely attributed to the greater emphasis on price stability relative to economic stabilization before the decade of the 1960s. See Romer and Romer (2002) and Orphanides (2003c) for discussions highlighting some underappreciated positive aspects of the policy environment during this period.
} 
of the 1970s. At that time, with inflation seemingly spiraling out of control, monetary policymakers in the United States changed course, eschewing the fine-tuning of the "New Economics" and concentrating instead on the goal of price stability. Indeed, in 1978, before he became Chairman of the Federal Reserve Board of Governors, Paul Volcker alluded to the nature of the required change: ${ }^{4}$

Wider recognition of the limits on the ability of demand management to keep the economy at a steady full employment path, especially when expectations are hypersensitive to the threat of more inflation, provides a more realistic starting point for policy formulation. (1978 p. 61.)

Following the costly disinflation of the early 1980s, less activist monetary policy, as evidenced by a reduced policy responsiveness to the perceived unemployment gap, contributed to a new era of relatively stable inflation and unemployment. Our model helps explain this evolution in the understanding of the role of monetary policy and the critical nature of maintaining well anchored inflation expectations as a means for ensuring long-term economic stability.

\section{Natural Rate Misperceptions and Policy Activism}

The success of activist stabilization policy rests on the assumption that the natural rate is a useful policy target. Under that assumption, adjusting aggregate demand relative to the economy's natural rate becomes the focus of short-term stabilization policy. Many of the policy errors associated with the Great Inflation of the late 1960s and 1970s can be traced to the pursuit of too low of a target of the natural rate of unemployment.

Figure 2 plots the rate of unemployment in the United States since the end of 1965 (the beginning of the Great Inflation) and two measures of the natural rate, a real-time measure, that is, perceptions as of the time shown, and a retrospective measure, that is, a current estimate. We take the current Congressional Budget Office (CBO) (2001, 2002) estimates of the natural rate of unemployment as truth. We construct a real-time series for the natural rate guided by written documents that offer glimpses of the thinking of policymakers of the 1960s and 1970s. During the 1960s, four percent was widely accepted

\footnotetext{
${ }^{4}$ During the early stages of the disinflationary policy pursued following the 1979 policy change, Chairman Volcker often stressed the importance of policies anchoring inflation expectations.
} 
as a reasonable working definition of the full employment rate of unemployment. ${ }^{5}$ Although we do not have precise information for the evolution of real-time perceptions of the natural rate of unemployment in the early 1970s, we do know that many estimates rose during that period, as reflected in various policy-related studies. ${ }^{6}$ Correspondingly, we posit that perceptions of the natural rate rose to around 4.5 percent in 1970 from the 4 percent estimates that prevailed earlier. ${ }^{7}$ Published accounts of Federal Reserve Board model exercises and estimates by the Council of Economic Advisers reported in the Economic Report of the President indicate that natural rate estimates continued to rise during the 1970s. From the late 1970s to the present, the CBO has regularly reported, explicitly or implicitly, its estimates of the natural rate in its publications regarding the economic and budget outlook, and for those years we use the contemporaneous values for our real-time estimates from these CBO publications. ${ }^{8}$

Comparison of the real-time perceptions likely held by policymakers at the time and our best current measures of the natural rate, then, provide a summary indicator of the potential policy errors that may be committed when an activist approach to stabilization policy is pursued. The top panel of Figure 3 shows our real-time and retrospective estimates of the natural rate of unemployment. The bottom panel of the figure plots the implied natural rate misperceptions - measured as the "true" value minus the real-time estimatefrom 1965 through 2003. As seen in the figure, natural rate misperceptions have tended to be highly persistent. The first-order serial correlation of this series over this sample is 0.98. Interestingly, the average magnitude of real-time misperceptions has declined over the past several decades. This appearance of diminishing errors may be overstated, however, because these calculations of "errors" implicitly assume that the current CBO method of

\footnotetext{
${ }^{5}$ Recollections of key policymakers of that period, including Walter Heller, Arthur Okun and Herbert Stein, who served as members and chairs of the Council of Economic Advisers in the 1960s and early 1970s, as well as Federal Reserve Chairman Arthur Burns serve as evidence of the wide acceptance of that estimate. See Burns (1979), Heller (1966), Okun (1962, 1970), and Stein (1984, 1996).

${ }^{6}$ See, for example, the discussion in Hall (1970) and Perry (1970).

${ }^{7}$ As a robustness check, we considered alternative paths for the real-time estimates in the model-based simulation exercises reported below. The precise dating of the evolution of perceptions regarding the rise of the natural rate from 4 percent in the late 1960s to 5 percent in the late 1970s does not materially influence our simulations, as both the pattern and size of the resulting misperceptions remain broadly similar under such alternatives, given that the retrospective estimates for this period, at about 6 percent, are always higher by a considerable margin.

${ }^{8}$ The real-time and retrospective natural rate estimates of the most recent five years are identical, reflecting the fact that the CBO's estimates are unchanged over that period.
} 
estimating the natural rate is correctly specified. The real-time and retrospective estimates in the latter part of the sample are constructed using the same method (based on a Kalman filter), while the "misperceptions" in the earlier part of the sample also reflect differences in methodology. If the current methodology used by the CBO proves to be inadequate, then the difference between real-time estimates and retrospective estimates in the 1980s and 1990s may widen in the future. ${ }^{9}$

Examples from the 1970s illustrate the problem associated with adopting an activist approach to stabilization policy when one may be mistaken as to the size or even the sign of the unemployment (or output) gap in real time. ${ }^{10}$ Consider the policy error of the early 1970s. With unemployment rising during and after the recession that started at the end of 1969, and in light of available estimates of the natural rate of unemployment, policymakers could have reasonably held the view that the economy was operating with considerable slack. The activist policy prescription at the time was clear cut: pursue additional monetary expansion to bring the unemployment rate down. Moreover, the existing slack should have led to some welcome disinflation despite the additional stimulus. Indeed, such a policy was pursued at the time. But, based on the retrospective estimates of the natural rate, it is now clear that that policy prescription represented a large error. The economic expansion pursued in 1971-73 pushed aggregate demand far above the economy's potential, as this is currently understood, fueling an increase in inflation. A similar error occurred after the 1975 recession, contributing to a further rise in inflation.

\section{A Simple Estimated Model of the U.S. Economy}

We examine the interaction of natural rate misperceptions, learning, and expectations for alternative monetary policy rules using a simple quarterly forward-looking model we developed in Orphanides and Williams (2002). The specification of the model is unchanged from that paper; however, we have reestimated the structural equations using the retrospective and real-time estimates of the natural rate of unemployment reported in the preceding section and, for simplicity, we have imposed a constant implicit natural rate of interest.

\footnotetext{
${ }^{9}$ See Orphanides and Williams (2002) for a detailed discussion of the sensitivity of measures of natural rate misperceptions to the assumption of the correct estimation method.

${ }^{10}$ See Orphanides and van Norden (2002) and Orphanides and Williams (2002) for summary documentation of the magnitude of the problem of real-time measurement of the natural rates of output and unemployment, respectively.
} 


\subsection{The Structural Model}

The model consists of the following two structural equations:

$$
\begin{gathered}
\pi_{t}=\phi_{\pi} \pi_{t+1}^{e}+\left(1-\phi_{\pi}\right) \pi_{t-1}+\alpha_{\pi}\left(u_{t}^{e}-u_{t}^{*}\right)+e_{\pi, t}, \quad e_{\pi} \sim \operatorname{iid}\left(0, \sigma_{e_{\pi}}^{2}\right), \\
u_{t}=\phi_{u} u_{t+1}^{e}+\chi_{1} u_{t-1}+\chi_{2} u_{t-2}+\left(1-\phi_{u}-\chi_{1}-\chi_{2}\right) u_{t}^{*}+\alpha_{u}\left(\tilde{r}_{t-1}^{a}-r^{*}\right)+e_{u, t}, \quad e_{u} \sim \operatorname{iid}\left(0, \sigma_{e_{u}}^{2}\right),
\end{gathered}
$$

where $\pi$ denotes the annualized log difference of the GNP or GDP price deflator, $u$ denotes the unemployment rate, $u^{*}$ denotes the true natural rate of unemployment, $\tilde{r}^{a}$ denotes the real interest rate based on the one-year Treasury bill, and $r^{*}$ the natural real rate of interest. This model combines forward-looking elements of the New Synthesis model studied by Goodfriend and King (1997), Rotemberg and Woodford (1999), Clarida, Gali and Gertler (1999), and McCallum and Nelson (1999), and others, with the intrinsic inflation and inertia in the level of economic activity featured in Fuhrer and Moore (1995), Brayton et al (1997), Smets (2000), Fuhrer and Rudebusch (forthcoming), and others.

The "Phillips curve" in this model (equation 1) relates inflation (measured as the annualized percent change in the GNP or GDP price index, depending on the period) during quarter $t$ to lagged inflation, expected future inflation, and expectations of the unemployment gap during the quarter, using the retrospective estimates of the natural rate discussed below. The estimated parameter $\phi_{\pi}$ measures the importance of expected inflation on the determination of inflation. The unemployment equation (equation 2) relates the unemployment gap during quarter $t$ to the expected future unemployment gap, two lags of the unemployment gap, and the lagged real interest rate gap. Here two elements importantly reflect forward-looking behavior. The first element is the estimated parameter $\phi_{u}$, which measures the importance of expected unemployment, and the second is the duration of the real interest rate, which serves as a summary of the influence of interest rates of various maturities on economic activity. Because data on long-run inflation expectations are not available, we limit the duration of the real rate to one year.

One difficulty in estimating this model is that expected inflation and unemployment are not directly observed. Instrumental variable and full-information maximum likelihood methods impose the restriction that the behavior of monetary policy and the formation of expectations be constant over time, neither of which appears tenable over our sample 
period (1969-2002). Instead, as in Orphanides and Williams (2002), we follow the approach suggested by Roberts (1997), and also employed by Rudebusch (2002), and use the Survey of Professional Forecasters as the source for proxies for expectations. Specifically, we use the median values of the forecasts provided in the Survey and posit that the relevant expectations are those formed in the previous quarter; that is, we assume that the expectations determining $\pi_{t}$ and $u_{t}$ are those collected in quarter $t-1$. Finally, to match the inflation and unemployment data as best as possible with these forecasts, we use first announced estimates of these series. ${ }^{11,12}$ Our primary sources for our data are the Real-Time Dataset for Macroeconomists and the Survey of Professional Forecasters, both currently maintained by the Federal Reserve Bank of Philadelphia (Zarnowitz and Braun (1993), Croushore (1993) and Croushore and Stark (2001)). Using ordinary least squares, we obtain the following estimates for our model between 1969:1 and 2002:2: ${ }^{13}$

$$
\begin{aligned}
& \pi_{t}=\underset{(0.086)}{0.529} \pi_{t+1}^{e}+\begin{array}{rrr}
0.471 & \pi_{t-1} & -0.304 \\
(--) & (0.093)
\end{array}\left(u_{t}^{e}-u_{t}^{*}\right)+e_{\pi, t}, \\
& S E R=1.38, D W=2.09, \\
& u_{t}=0.221 u_{t+1}^{e}+1.262 u_{t-1}-0.529 u_{t-2}+0.045 u_{t}^{*}+0.033\left(\tilde{r}_{t-1}^{a}-r^{*}\right)+e_{u, t} \text {, } \\
& \begin{array}{lllll}
(0.080) & (0.104) & (0.068) & (0.022) & (0.013)
\end{array} \\
& S E R=0.29, D W=2.08,
\end{aligned}
$$


To complete our model for simulations, we impose the expectations theory of the term structure whereby the one-year rate equals the expected average of the federal funds rate over four quarters.

\subsection{Historical Monetary Policy}

In addition to the equations for inflation and the unemployment rate, we estimate a monetary policy rule according to which the federal funds rate is determined by the lagged funds rate, the forecast of inflation over the next year (defined to be the four-quarter change from $t-1$ to $t+3$ where $t$ denotes the period for which the funds rate is set), the forecasted change in the unemployment rate over the next year, and the unemployment gap (the unemployment rate less the real-time estimate of the natural rate) forecasted to occur in three quarters:

$$
i_{t}=\theta_{i} i_{t-1}+\left(1-\theta_{i}\right)\left(r^{*}+\pi^{*}\right)+\theta_{\pi}\left(\pi_{t+3}^{e}-\pi^{*}\right)+\theta_{u}\left(u_{t+3}^{e}-\hat{u}_{t}^{*}\right)+\theta_{\Delta u}\left(u_{t+3}^{e}-u_{t-1}\right)+\epsilon_{i, t}
$$

For both estimation and simulation purposes, we assume that the central bank responds to the private sector forecasts of inflation and the unemployment rate in setting policy. As discussed in Orphanides (2003c) and Orphanides and Williams (2002), this specification nests both a version of the classic Taylor rule (Taylor, 1993), which excludes the change in unemployment and lagged interest rate terms (that is sets $\theta_{i}=\theta_{\Delta u}=0$ ), as well as rules robust to natural rate misperceptions (the limiting case with $\theta_{i}=1$ and $\theta_{u}=0$ )

To allow the rule to capture the reduction of activism in Federal Reserve policy following the summer of 1979 , we allow for a break in the policy rule at that time. Other things equal, a reduction in activism should be reflected in this rule by a reduction in the policy responsiveness to the perceived gap in the forecast of unemployment from its natural rate, $\theta_{u}$. To examine this effect in a parsimonious manner, we follow the suggestion in Orphanides (forthcoming) and focus on a specification that allows for a break in the $\theta_{u}$ parameter, keeping remaining parameters of the policy reaction functions fixed. ${ }^{14}$ Allowing for this break, our estimated policy rule is given by:

\footnotetext{
${ }^{14} \mathrm{~A}$ stability test rejects the constancy of all parameters over the two subsamples. However, once we allow for the break in $\theta_{u}$, the stability of individual remaining parameters over the two subsamples cannot be rejected. As a robustness check for our model, we also examined simulations based on a specification of the policy rule that allows breaks in two parameters, $\theta_{u}$ and $\theta_{\pi}$. In that specification, the point estimates of both $\theta_{\pi}$ and $\theta_{u}$ are slightly lower in the first subsample, but the difference is small and does not qualitatively influence our simulation results.
} 


$$
\begin{aligned}
& i_{t}=0.750 i_{t-1}+0.250\left(r^{*}+\pi^{*}\right)+0.779\left(\pi_{t+3}^{e}-\pi^{*}\right)-0.673\left(u_{t+3}^{e}-u_{t-1}\right)+ \\
& \begin{array}{llll}
(0.044) & (--) & (0.130)
\end{array} \\
& \left(\begin{array}{lll}
-1.131+0.561 D & D
\end{array}\right)\left(u_{t+3}^{e}-\hat{u}_{t}^{*}\right)+\epsilon_{i, t}, \\
& (0.197) \quad(0.158)
\end{aligned}
$$

$$
S E R=1.02, D W=1.90,
$$

where $D$ is a dummy variable equaling zero before 1979:3 and one thereafter. Conditional on a value for the natural rate of interest, $r^{*}$, estimation of this policy rule also provides an estimate of the implicit inflation target, $\pi^{*}$. Assuming $r^{*}=3.2$ percent, as suggested by the estimation of equation 2, yields an estimate of 2.7 percent for $\pi^{*}$ with a standard error equal to 0.15 percent.

As can be seen, and consistent with the narrative evidence, the estimated policy reaction function points to a substantial reduction in policy activism following the summer of 1979 compared to the earlier period. We note that this policy rule satisfies the standard stability condition in models with adaptive or rational expectations that the long-run response of the nominal interest rate to a change in the inflation rate exceeds unity. We do not find evidence that policy was inherently destabilizing in the pre-1979 sample, but instead only that it was more activist. This contrasts with the well-known findings reported by Clarida, Gali and Gertler (2000), based on a similar specification, but employing the output gap (instead of the unemployment gap) and relying on instrumental variables analysis with ex post data (instead of real-time data and forecasts). They suggested that the response of policy to inflation was unstable in the pre-1979 period. However, as documented by Orphanides (forthcoming), their findings are overturned when information actually available to policymakers in real time is used to estimate the policy rule that they specify. Even when we allow for breaks in the policy response to both expected inflation and to the perceived unemployment gap in our rule, which, as noted earlier, suggests that the coefficient on the inflation forecast is a bit lower in the pre-1979 sample, we find that the estimation provides no evidence supporting the hypothesis of policy instability. 


\section{Expectations Formation}

Following Orphanides and Williams (2003, forthcoming), we assume that agents reestimate their forecasting models each period using a constant gain algorithm that places more weight on recent observations. ${ }^{15}$ Given the structure of the model, agents need to forecast inflation, the unemployment rate, and the federal funds rate for up to four quarters in the future. As noted above, we assume the policymaker uses private agents' forecasts in setting policy.

\subsection{Least Squares Learning with Finite Memory}

Under perfect knowledge with no shocks to the natural rate of unemployment, the predictable components of inflation, the unemployment rate, and the funds rate each depend on a constant, one lag each of the inflation and the ex post real funds rate (the difference between the nominal funds rate and the inflation rate), and two lags of the unemployment rate. We assume that agents estimate forecasting equations for the three variables using a restricted VAR of this form. They then construct multi-period forecasts from the estimated VAR. To fix notation, let $Y_{t}$ denote the $1 \times 3$ vector consisting of the inflation rate, the unemployment rate, and the federal funds rate, each measured at time $t: Y_{t}=\left(\pi_{t}, u_{t}, i_{t}\right)$; let $X_{t}$ be the $5 \times 1$ vector of regressors in the forecast model: $X_{t}=\left(1, \pi_{t-1}, u_{t-1}, u_{t-2}, i_{t-1}-\pi_{t-1}\right)$; let $c_{t}$ be the $5 \times 3$ vector of coefficients of the forecasting model.

Using data through period $t$, the least squares regression parameters for the forecasting model can be written in recursive form:

$$
\begin{aligned}
c_{t} & =c_{t-1}+\kappa_{t} R_{t}^{-1} X_{t}\left(Y_{t}-X_{t}^{\prime} c_{t-1}\right), \\
R_{t} & =R_{t-1}+\kappa_{t}\left(X_{t} X_{t}^{\prime}-R_{t-1}\right),
\end{aligned}
$$

where $\kappa_{t}$ is the gain.

Under the assumption of least squares learning with infinite memory, $\kappa_{t}=1 / t$, so as $t$ increases, $\kappa_{t}$ converges to zero. As a result, as the data accumulate this mechanism converges to the correct expectations functions and the economy converges to the perfect knowledge benchmark solution. As noted above, to formalize perpetual learning - as would be implied

\footnotetext{
${ }^{15}$ See also Sargent (1999), Cogley and Sargent (2001), Evans and Honkapohja (2001), and Gaspar and Smets (2002) for related treatments of learning. A separate strand of the literature has focused on the problem of estimating the implicit inflation target of the central bank, assuming that other parameters are known. See e.g. Bomfim et al (1997), Erceg and Levin (2003), Kozicki and Tinsley (2003), and Rudebusch and $\mathrm{Wu}(2003)$.
} 
by the presence of structural changes such as shifts in the natural rate of unemploymentwe replace the decreasing gain in the infinite memory recursion with a small constant gain, $\kappa>0 .{ }^{16}$

With imperfect knowledge, expectations are based on the perceived law of motion of the inflation process, governed by the perpetual learning algorithm described above. The model under imperfect knowledge consists of the structural equations for inflation, the output gap, the federal funds rate (the monetary policy rule), and the forecasts generated from the forecasting model.

We should emphasize that in the limit of perfect knowledge (that is, as $\kappa \rightarrow 0$ ) and assuming a constant natural rate of unemployment, the expectations function above converges to rational expectations, and the stochastic coefficients for the forecasting model converge to those implied by the structural model equations under rational expectations. As explained in Orphanides and Williams (forthcoming), this modeling approach accommodates the Lucas critique in the sense that expectations formation is endogenous and adjusts to changes in policy or structure; and, although expectations are "imperfectly" rational, in that agents are required to estimate the reduced form processes needed to form expectations, the resulting expectations are close to being efficient.

\subsection{Calibrating the Learning Rate}

A key parameter for the constant-gain-learning algorithm is the updating rate $\kappa$. To calibrate this parameter we examined how well different values of $\kappa$ fit either the expectations data from the Survey of Professional Forecasters, or, based on our model, the actual data on inflation and unemployment.

To examine the fit of the Survey of Professional Forecasters (SPF), we generated a time series of forecasts using a recursively estimated VAR for the inflation rate, the unemployment rate, and the federal funds rate. In each quarter we reestimated the model using all historical data available during that quarter (generally from 1948 through the most recent observation). We allowed for discounting of past observations by using geometrically declining weights. We found that discounting past data at about 1 percent per quarter yielded

\footnotetext{
${ }^{16}$ In terms of forecasting performance, the "optimal" choice of $\kappa$ depends on the relative variances of the transitory and permanent shocks, as in the relationship between the Kalman gain and the signal-to-noise ratio in the case of the Kalman filter.
} 
forecasts closest on average to the SPF over 1968-2002. ${ }^{17}$ This corresponds to an updating gain of about 2 percent per quarter during the 1970s and 1-1/2 percent per quarter in the 1990s.

To examine the degree of discounting that best fits the historical data on inflation and unemployment, given our structural model and learning process, we simulated the model from 1966 forward for alternative values of $\kappa$ and examined the mean squared deviations of the simulated path from the actual paths of inflation and unemployment. (Details on simulation of the model and setting of initial conditions are provided below.) These simulations suggested that our model with values of $\kappa$ between 0.01 and 0.04 matched the data better than when $\kappa$ was set at lower or higher values.

In light of these results, in the following we use $\kappa=0.02$ as a baseline value. As a robustness check, we also examined the sensitivity of our model to lower and higher values.

\section{The Interaction of Learning, Misperceptions, and Policy}

We examine a set of alternative counterfactual simulations to investigate the role of learning, natural rate misperceptions, and policy for understanding the behavior of inflation and unemployment and the evolution of policy. We start our simulations at the beginning of 1966, which corresponds to what many observers consider to be the beginning of the Great Inflation in the United States.

\subsection{Initial Conditions}

The states of the model economy with learning are: the current value and one lag each of the inflation rate and the federal funds rate, the current value and two lags of the unemployment rate, the true natural rate of unemployment, the real-time estimate of the natural rate, the shocks to the structural equations, and the matrices $C$ and $R$ for the forecasting model. We initialize the $C$ and $R$ matrices using estimates of the forecasting model by ordinary least squares on data from 1948 through 1965.

Based on our calibration of the learning rate using survey data, we set $\kappa=0.02$ and compute the implied forecasts of inflation, the unemployment rate, and the federal funds

\footnotetext{
${ }^{17}$ This finding is also in line with the discounting reported by Sheridan (2003) as best for explaining the inflation expectations data reported in the Livingston Survey.
} 
rate over 1966:1 - 2003:2. Using these forecasts as data, we then compute tracking residuals for all model equations so that the model identically matches the data over the full sample.

\subsection{The Role of Natural Rate Misperceptions}

Our first experiment is a simulation in which policy follows the estimated policy rule (including residuals), but the policymaker is assumed to observe the true value of the natural rate of unemployment in real time. That is, there are no natural rate misperceptions. Note that because the policy rule matches history under the assumption that the policy was based on the real-time estimates of the natural rate, the simulation boils down to adding innovations to the policy rule equal to the coefficient on the unemployment gap multiplied by the real-time misperceptions shown in Figure 3.

Absent natural rate misperceptions, inflation would have been relatively stable in the 1970s according to the model. Figure 4 shows the historical paths (the thick lines) and the simulated paths of the rates of inflation (four-quarter change in the price level) and unemployment. In contrast to the historical experience when inflation reached into double digits, the inflation rate with no natural rate misperceptions remains in a relatively narrow range of about 2 percent to 4 percent during the 1970s. The stability in inflation is achieved through a tighter path for policy starting in 1966 that drives the unemployment rate above its historical path. This effective stabilization of inflation avoids the rise in unemployment associated with the Volcker disinflation occurring at the end of the decade and into the early 1980s.

The policy without natural rate misperceptions also avoids the damaging shift in the perceived law of motion of inflation evident in the historical data. Absent the rise in inflation in the late 1960s and 1970s, the expected level of inflation also remains subdued. In addition, the perceived persistence in inflation remains moderate. The thick solid line in Figure 5 shows the estimated sum of coefficients on lagged inflation in the forecasting equation for inflation that incorporates learning, as described above. This statistic usefully summarizes agents' perceptions of the persistence in inflation. Based on the historical data, the perceived persistence in inflation rises to about 0.9 by $1975 .^{18}$ In contrast, under the same policy,

\footnotetext{
${ }^{18}$ This rise in perceived inflation persistence in our model is a manifestation of the real-world accumulation of evidence against the hypothesis of a long-run tradeoff between unemployment and inflation and in favor of the "accelerationist" view during the 1970s.
} 
but absent natural rate misperceptions, the perceived persistence in inflation would have remained moderate throughout the 1960s and 1970s. In this simulation, the trend rise in inflation associated with the "Great Inflation" is avoided and inflation expectations remain well anchored.

\subsection{The Role of Learning}

Even in the presence of policy errors driven by misperceptions of the natural rate of unemployment, economic outcomes during the Great Inflation could have been much less unfavorable if expectations had remained well anchored and governed by the forecasting processes in place before. With regard to the persistence of inflation, had the policy errors of the late 1960s and 1970s not resulted in its steep increase, inflation would have been contained much more easily and price stability restored at a lower cost. To illustrate the role of learning in this case, Figure 6 presents a counterfactual experiment where the historical policy rule is followed, and policy continues to make the errors associated with natural rate misperceptions, but the process governing the formation of expectations is unaffected by the resulting adverse outcomes and continues to be governed by the reduced form VAR in place at the beginning of the simulation, in 1966. Thus, in this simulation, expectations of inflation remain by design well anchored through time. As can be seen, despite the policy errors due to the natural rate misperceptions, in the absence of learning, that is if the favorable expectations mechanism in place before the Great Inflation could have been maintained, economic outcomes would have been significantly better.

\subsection{The Role of Policy Activism}

The simulations above suggest that under some conditions the activist policy pursued during the Great Inflation could have been successful. In particular, if policymakers could have avoided misperceptions in the natural rate or, if expectations could have remained favorable even in the face of the policy errors caused by the combination of policy activism and natural rate misperceptions, the stagflation of the 1970s would not have occurred. But, of course, neither of these conditions could be taken for granted as the basis for policy design, and the possibility that they might fail, as they did during the Great Inflation, limits the scope for activist stabilization policy. An insufficient understanding of these limits and of 
the long-term damage to expectations formation resulting from activist policy errors likely contributed to the policy failure of the 1970s.

A natural question is whether a less activist approach, such as the one adopted following the policy change in 1979, would have represented better policy during the Great Inflation as well. To examine the role of policy activism, our third set of experiments examines what the historical outcomes could have been in the presence of learning and of the observed natural rate given by our real-time estimates if policy were driven by a less activist approach than the one observed. ${ }^{19}$ Figures 7 and 8 summarize the results from two such experiments. In one, policy does not respond to the unemployment gap at all, and in the other, policy follows the estimated post-1979 reaction function.

If policymakers had followed either of these policies starting in 1966, the rise in inflation in the 1970s would have been less pronounced and the unemployment rate would have been lower on average than it actually was. The finding that both inflation and unemployment would have been lower in the 1970s if the Fed had followed the estimated post-1979 reaction function during the late 1960s and 1970s, or if the Fed had not responded to the unemployment (or output) gap, differs from the results of Judd and Rudebusch (1998) and Orphanides (2003b), respectively, who find that such policies would have implied lower inflation, but at the cost of lower output during the 1970s (implying a higher unemployment rate). These analyses were based on the assumption of backward-looking accelerationist models that implicitly treat inflation expectations as invariant to monetary policy. Our results illustrate the importance of endogenous formation of expectations in affecting the tradeoffs available to policymakers in designing monetary policies.

Importantly, as can be seen in Figure 8, under either policy, and even with the perpetual learning process governing the formation of expectations, the natural rate misperceptions of the 1960s and 1970s would not have been sufficient to destabilize the inflation expectations process. By maintaining well-anchored inflation expectations throughout the 1970s, these policies would have avoided the stagflationary outcomes of the decade.

\footnotetext{
${ }^{19}$ This experiment is a first step towards investigating the design of efficient monetary policy in our estimated model, accounting for the role of perpetual learning and its influence on the inflation expectations process. An active literature over the past several years has been exploring issues related to efficient policy design in the presence of uncertainty regarding models, data, and natural rates. See e.g. Levin et al (1999, 2003), Orphanides (2003a), Orphanides et al (2000), Orphanides and Williams (2002), Rudebusch (2001, 2002), and references therein.
} 
Indeed, the realization of the role of the policy mistakes of the 1970s in destabilizing inflation expectations was a key reason leading to the policy change in 1979. As Stephen Axilrod summarized: ${ }^{20}$

Not all exogenous forces are purely exogenous. Rising inflationary expectations in the late 1970s were in part the product of earlier monetary policies (as well as other events) as these policies affected attitudes toward the future, ... but once embedded the expectations were exogenous to and influenced current policiesas in October 1979. (1985, p. 14.)

\subsection{Robustness}

As a robustness check for our key results regarding the wisdom of reduced policy activism, we also examined counterfactual simulations under alternative assumptions regarding learning and the formation of expectations. We concentrated our attention on the robustness of the finding that if policy during the Great Inflation had followed the less activist approach adopted after 1979, inflation expectations would have remained well behaved during the 1970s and the stagflation experienced during that decade would have been avoided.

We considered the sensitivity of our results to the updating parameter $\kappa$ by comparing counterfactual simulations for three different values of $\kappa=0.01,0.02,0.03$ for the counterfactual policy rule experiments. Qualitatively, the results are quite similar across the three values of $\kappa$. In fact, the rise in the rate of inflation during the late 1970s appears less pronounced both for the smaller and larger values of $\kappa$ than in the baseline case of $\kappa=0.02$. In this sense, our baseline choice for $\kappa$ is conservative in terms of the effects of the interaction of learning and policy errors.

We also examined the sensitivity of our results for the choice of initial conditions governing the formation of expectations. Instead of the initial conditions estimated through the end of 1965, we examined simulations with estimated initial conditions later in the sample. We also considered as initial conditions the reduced-form coefficients corresponding to the model-consistent solution of the model. In either case, these alternative initial conditions are somewhat less favorable than the ones used in the simulations reported before. As a result, inflation outcomes for the early 1970s are worse under these alternatives relative

\footnotetext{
${ }^{20}$ Stephen Axilrod, a member of the Federal Reserve Board staff, served as the FOMC Economist at the time of the 1979 policy change.
} 
to our baseline specification. However, even with these less favorable initial conditions, if policy had followed the estimated post-1979 rule, our simulations suggest that inflation in the mid- and late-1970s would have been considerably lower, and as a result the stagflation of the 1970s would not have occurred.

\section{Conclusion}

In principle, the activist approach to macroeconomic stabilization that underlay the monetary policy decisions of the late 1960s and 1970s could have been successful in stabilizing economic fluctuations while maintaining price stability if policymakers had had accurate assessments of the natural rate of unemployment. In the event, the natural rate estimates proved to be highly inaccurate, and the unemployment gap (and the related output gap) turned out to be a poor guide for policy in practice. On their own, these policy errors would not have been disastrous to macroeconomic performance if inflation expectations had remained as favorable as they were before the Great Inflation got underway. But, in a dynamic economy with agents continuously learning, the rise in inflation resulting from the policy errors and the activist approach to stabilization policy unmoored inflation expectations, eventually resulting in the stagflation of the 1970s. Towards the end of that decade, the fatal flaw in activist policy strategies was recognized. Out of this experience grew the realization that active control of resource utilization should be downplayed and that policies focusing on price stability could achieve better outcomes in terms of the stabilization of both inflation and unemployment. 


\section{References}

Axilrod, Stephen (1985), "U.S. Monetary Policy in Recent Years: An Overview," Federal Reserve Bulletin, January, 14-24.

Bomfim, Antulio, Robert Tetlow, Peter von zur Muehlen, and John C. Williams (1997), "Expectations, Learning and the Cost of Disinflation," in: Monetary Policy and the Inflation Process, Basel, Switzerland: Bank for International Settlements.

Brayton, Flint; Mauskopf, Eileen; Reifschneider, David; Tinsley, Peter and Williams, John. "The Role of Expectations in the FRB/US Macroeconomic Model." Federal Reserve Bulletin, April 1997, 83(4), pp. 227-245.

Bullard, James and Stefano Eusepi (2003), "Did the Great Inflation Occur Despite Policymaker Commitment to a Taylor Rule?" Federal Reserve Bank of St. Louis Working Paper 2003-012A, June.

Burns, Arthur (1979), The Anguish of Central Banking, The 1979 Per Jacobsson Lecture, Belgrade, Yugoslavia, September 30.

Clarida, Richard, Jordi Gali, and Mark Gertler (1999), "The Science of Monetary Policy," Journal of Economic Literature, 37(4), 1661-1707, December.

Clarida, Richard, Jordi Gali, and Mark Gertler (2000), "Monetary Policy Rules and Macroeconomic Stability: Evidence and Some Theory," Quarterly Journal of Economics, 147180, February.

Cogley, Timothy and Sargent, Thomas (2001), "Evolving Post-World War II U.S. Inflation Dynamics," in NBER Macroeconomics Annual.

Collard, Fabrice and Harris Dellas (2003), "The Great Inflation of the 1970s," mimeo, October.

Congressional Budget Office (2001), "CBO's Method for Estimating Potential Output: An Update," Washington, DC: Government Printing Office (August).

Congressional Budget Office (2002), The Budget and Economic Outlook: An Update. Washington DC: Government Printing Office (August).

Croushore, Dean (1993), "Introducing: The Survey of Professional Forecasters," Federal Reserve Bank of Philadelphia Business Review, November/December, 3-13.

Croushore, Dean and Tom Stark (2001), "A Real-Time Data Set for Macroeconomists," Journal of Econometrics 105, 111-130, November.

Cukierman, Alex and Francesco Lippi (2003), "Endogenous Monetary Poilicy with Unobserved Potential Output," mimeo, December.

Erceg, Christopher J. and Andrew Levin (2003), "Imperfect Credibility and Inflation Persistence," Journal of Monetary Economics. 50(4) 915-944, May.

Evans, George and Honkapohja, Seppo (2001), Learning and Expectations in Macroeconomics. Princeton: Princeton University Press.

Fuhrer, Jeffrey C. and George R. Moore (1995), "Inflation Persistence," Quarterly Journal of Economics, 110(1), 127-59. 
Fuhrer, Jeffrey C. and Glenn D. Rudebusch (forthcoming), "Estimating the Euler Equation for Output," Journal of Monetary Economics.

Friedman, Milton (1947), "Lerner on the Economics of Control," Journal of Political Economy, 55(5), October, 405-416.

Gaspar, Vitor and Smets, Frank (2002), "Monetary Policy, Price Stability and Output Gap Stabilisation," International Finance, 5(2), Summer, 193-211.

Goodfriend, Marvin, and Robert King (1997), "The New Neoclassical Synthesis and the Role of Monetary Policy," NBER Macroeconomics Annual, (12), 231-283.

Hall, Robert E. (1970), "Why Is the Unemployment Rate So High at Full Employment?" Brookings Papers on Economic Activity, 3, 369-402.

Heller, Walter W. (1966), New Dimensions of Political Economy, Cambridge, MA: Harvard University.

Judd, John and Glenn Rudebusch (1998), "Taylor's Rules and the Fed: 1970-1997," FRBSF Economic Review, 3, 3-16.

Kozicki, Sharon and Peter A. Tinsley (2003), "Permanent and Transitory Policy Shocks in Macro Models under Asymmetric Information," Federal Reserve Bank of Kansas City, mimeo.

Lerner, Abba (1944), The Economics of Control, New York: Macmillan.

Levin, Andrew, Volker Wieland and John Williams (1999), "Robustness of Simple Monetary Policy Rules under Model Uncertainty," in Monetary Policy Rules, John B. Taylor (ed.), Chicago: University of Chicago.

Levin, Andrew, Volker Wieland and John Williams (2003), "The Performance of ForecastBased Policy Rules under Model Uncertainty," American Economic Review, 93(3), 622645 , June.

McCallum, Bennett T. and Edward Nelson (1999), "Performance of Operational Policy Rules in an Estimated Semiclassical Structural Model." in Monetary Policy Rules, John B. Taylor (ed.), Chicago: University of Chicago, 15-45.

Okun, Arthur (1962), "Potential Output: Its Measurement and Significance," in American Statistical Association 1962 Proceedings of the Business and Economic Section, Washington, D.C.: American Statistical Association.

Okun, Arthur (1970), The Political Economy of Prosperity, Brookings, Washington D.C.

Orphanides, Athanasios (2002), "Monetary Policy Rules and the Great Inflation," American Economic Review, 92(2), 115-120, May.

Orphanides, Athanasios (2003a), "Monetary Policy Evaluation With Noisy Information," Journal of Monetary Economics, 50(3), 605-631, April.

Orphanides, Athanasios (2003b), "The Quest for Prosperity Without Inflation," Journal of Monetary Economics, 50(3), 633-663, April.

Orphanides, Athanasios (2003c), "Historical Monetary Policy Analysis and the Taylor Rule," Journal of Monetary Economics, 50(5), 983-1022, July. 
Orphanides, Athanasios (forthcoming), "Monetary Policy Rules, Macroeconomic Stability and Inflation: A View from the Trenches," Journal of Money, Credit and Banking.

Orphanides, Athanasios, Richard Porter, David Reifschneider, Robert Tetlow and Frederico Finan (2000), "Errors in the Measurement of the Output Gap and the Design of Monetary Policy," Journal of Economics and Business, 52(1/2), 117-141, January/April.

Orphanides, Athanasios and Simon van Norden (2002), "The Unreliability of Output Gap Estimates in Real Time," Review of Economics and Statistics, 84(4), 569-583, November.

Orphanides, Athanasios and John C. Williams (2002), "Robust Monetary Policy Rules with Unknown Natural Rates", Brookings Papers on Economic Activity, 2:2002, 63-118.

Orphanides, Athanasios and John C. Williams (2003), "Inflation scares and forecast-based monetary policy", FRB San Francisco Working Paper, 2003-11 and FEDS 2003-41, August.

Orphanides, Athanasios and John C. Williams (forthcoming) "Imperfect Knowledge, Inflation Expectations and Monetary Policy," in Inflation Targeting, Ben Bernanke and Michael Woodford (eds.), Chicago: University of Chicago Press.

Perry, George L. (1970), "Changing Labor Markets and Inflation," Brookings Papers on Economic Activity, 3, 411-448.

Phillips, A. W. (1954), "Stabilisation Policy in a Closed Economy," Economic Journal, 290-323, June.

Roberts, John M. (1997), "Is Inflation Sticky?" Journal of Monetary Economics, 39, 173196.

Romer, Christina D. and David H. Romer (2000), "Federal Reserve Information and the Behavior of Interest Rates," American Economic Review, 90(3), June, 429-457.

Romer, Christina and David Romer (2002), "A Rehabilitation of Monetary Policy in the 1950s" American Economic Review, 92(2), May.

Rotemberg, Julio J. and Michael Woodford (1999), "Interest Rate Rules in an Estimated Sticky Price Model," in Monetary Policy Rules, John B. Taylor (ed.), Chicago: University of Chicago Press, 57-119.

Rudebusch, Glenn (2001), "Is the Fed Too Timid? Monetary Policy in an Uncertain World" Review of Economics and Statistics, 83(2), 203-17, May.

Rudebusch, Glenn (2002) "Assessing Nominal Income Rules for Monetary policy with Model and Data Uncertainty," Economic Journal, 112, 402-432, April.

Rudebusch, Glenn and Tao Wu (2003), "A Macro-Finance Model of the Term Structure, Monetary Policy, and the Economy" FRB/SF Working paper 2003-17, September.

Sargent, Thomas J. (1999), The Conquest of American Inflation, Princeton: Princeton University Press.

Sheridan, Niamh (2003), "Forming Inflation Expectations," Johns Hopkins University, mimeo, April.

Smets, Frank (2000), "What Horizon for Price Stability," European Central Bank Working Paper No 24. 
Stein, Herbert (1984), Presidential Economics, New York: Simon and Schuster.

Stein, Herbert (1996), "A Successful Accident: Recollections and Speculations about the CEA," 10(3), 3-21, Summer.

Taylor, John B. (1993), "Discretion versus Policy Rules in Practice," Carnegie-Rochester Conference Series on Public Policy, 39, December, 195-214.

Tobin, James (1966), National Economic Policy, New Haven: Yale University Press.

Tobin, James (1972), New Economics One Decade Older, Princeton: Princeton University Press.

Volcker, Paul, A. (1978), The Rediscovery of the Business Cycle, New York: The Free Press.

Zarnowitz, Victor and Phillip A. Braun (1993), "Twenty-two Years of the NBER-ASA Quarterly Economic Outlook Surveys: Aspects and Comparisons of Forecasting Performance," in Business Cycles, Indicators, and Forecasting, James H. Stock and Mark W. Watson (eds.), Chicago: University of Chicago Press, 11-84. 
Figure 1

Inflation Rate

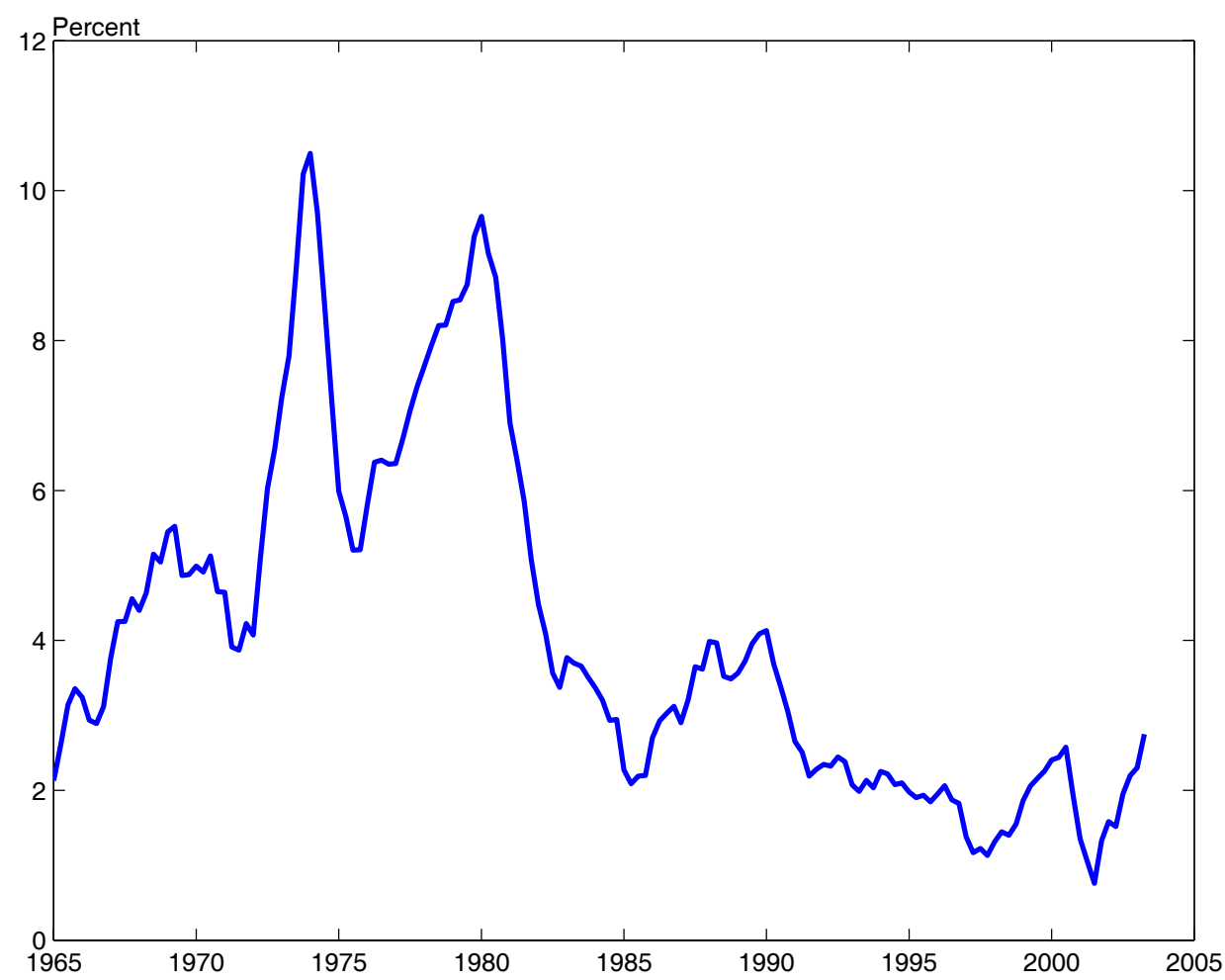

Notes: Inflation measured by the change of the output deflator (annual rate). 
Figure 2

Unemployment and its Natural Rate

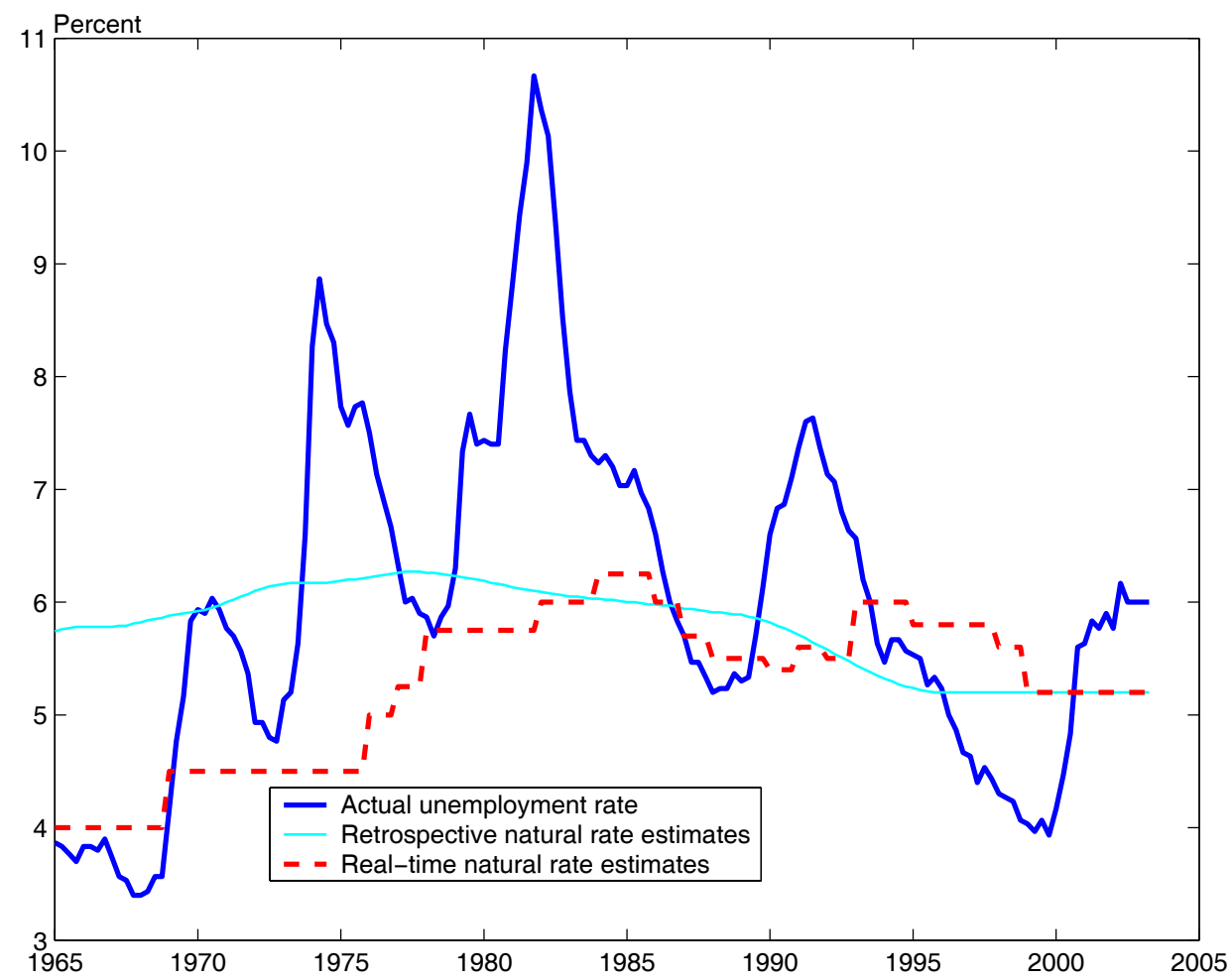

Notes: The retrospective natural rate reflects the current estimate of the NAIRU from the Congressional Budget Office. The real-time series is as described in the text. 
Figure 3

The Natural Rate and Natural Rate Misperceptions

Estimates of the Natural Rate of Unemployment

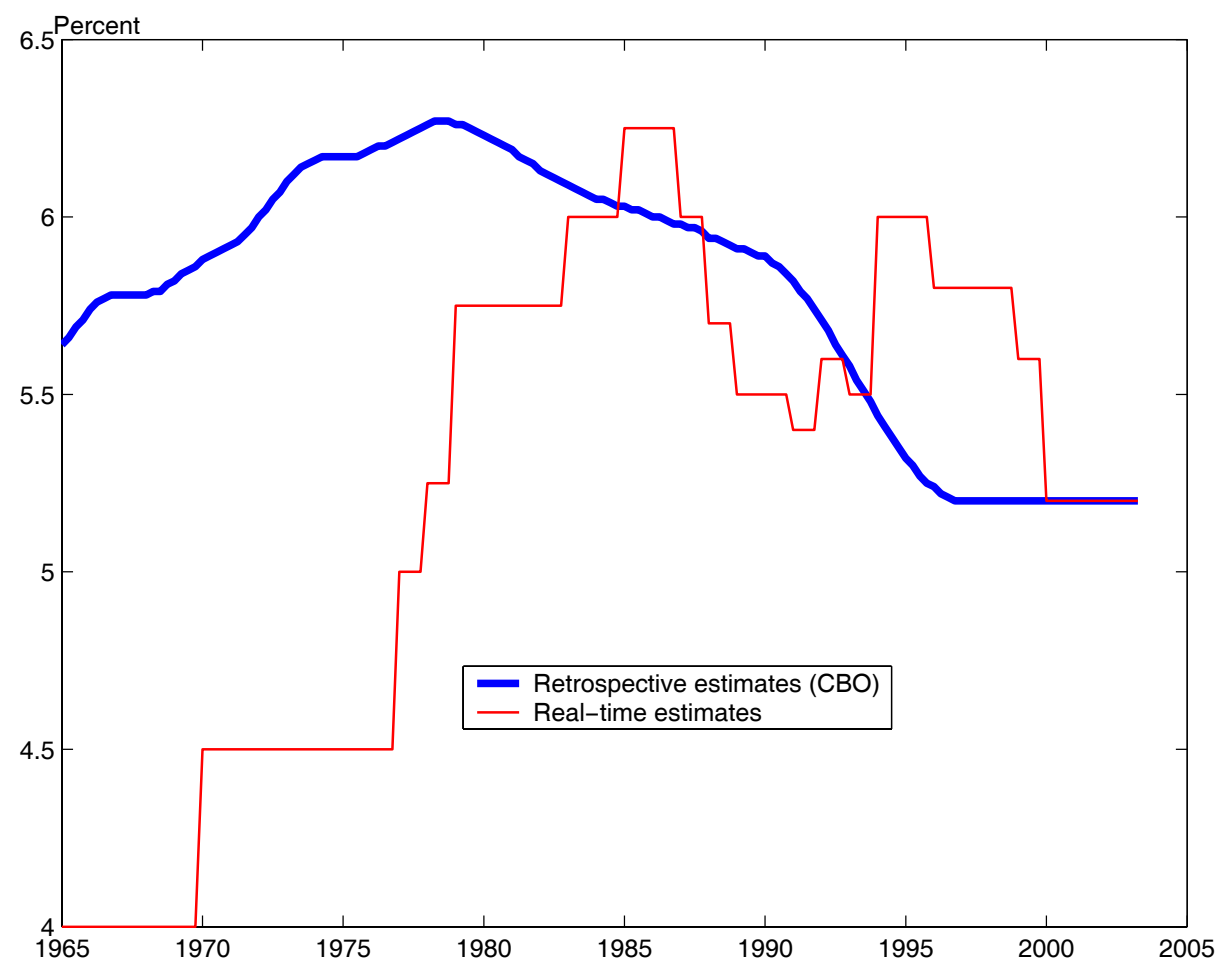

Real-Time Misperceptions of the Natural Rate

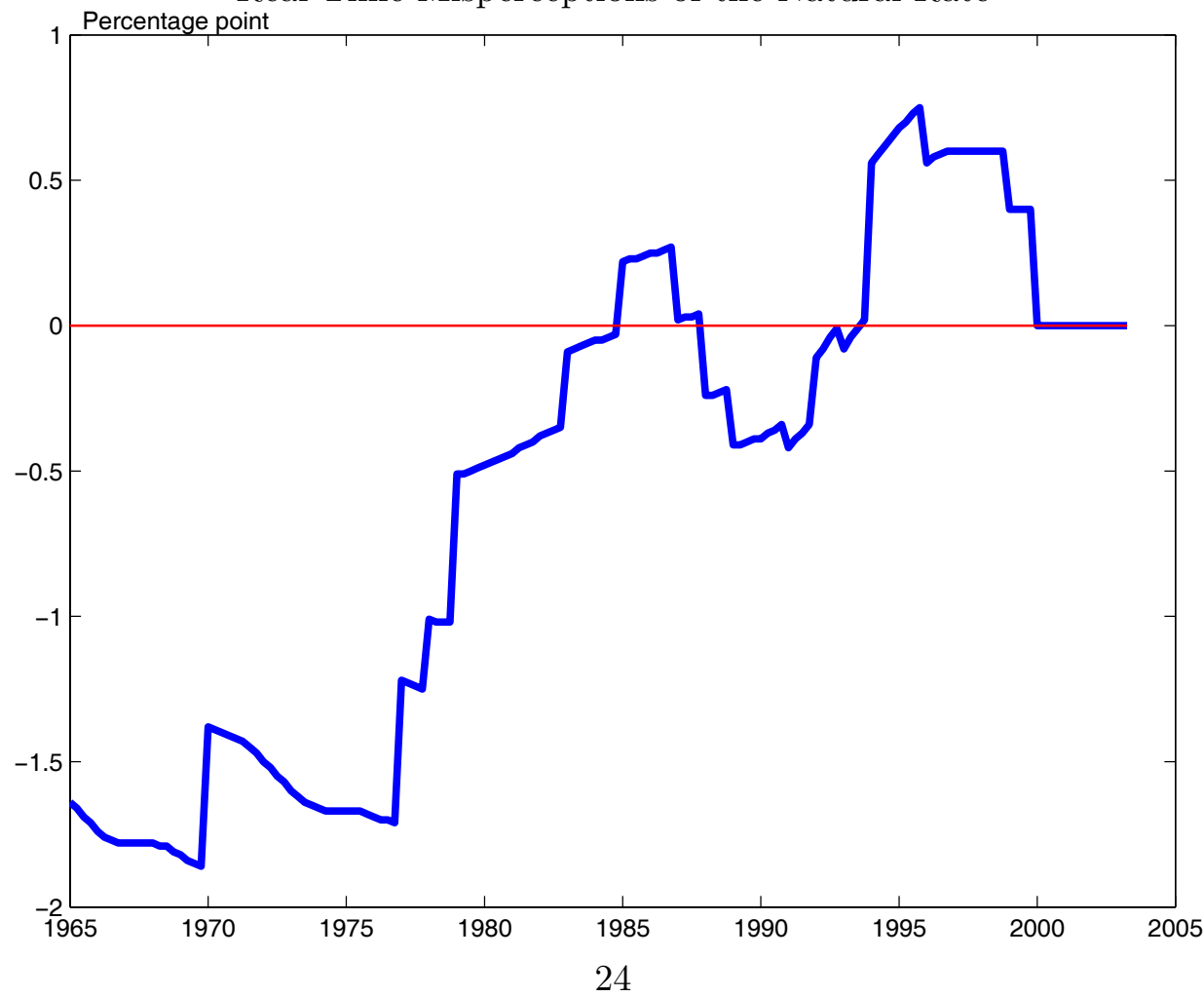


Figure 4

\section{Outcomes with No Natural Rate Misperceptions}
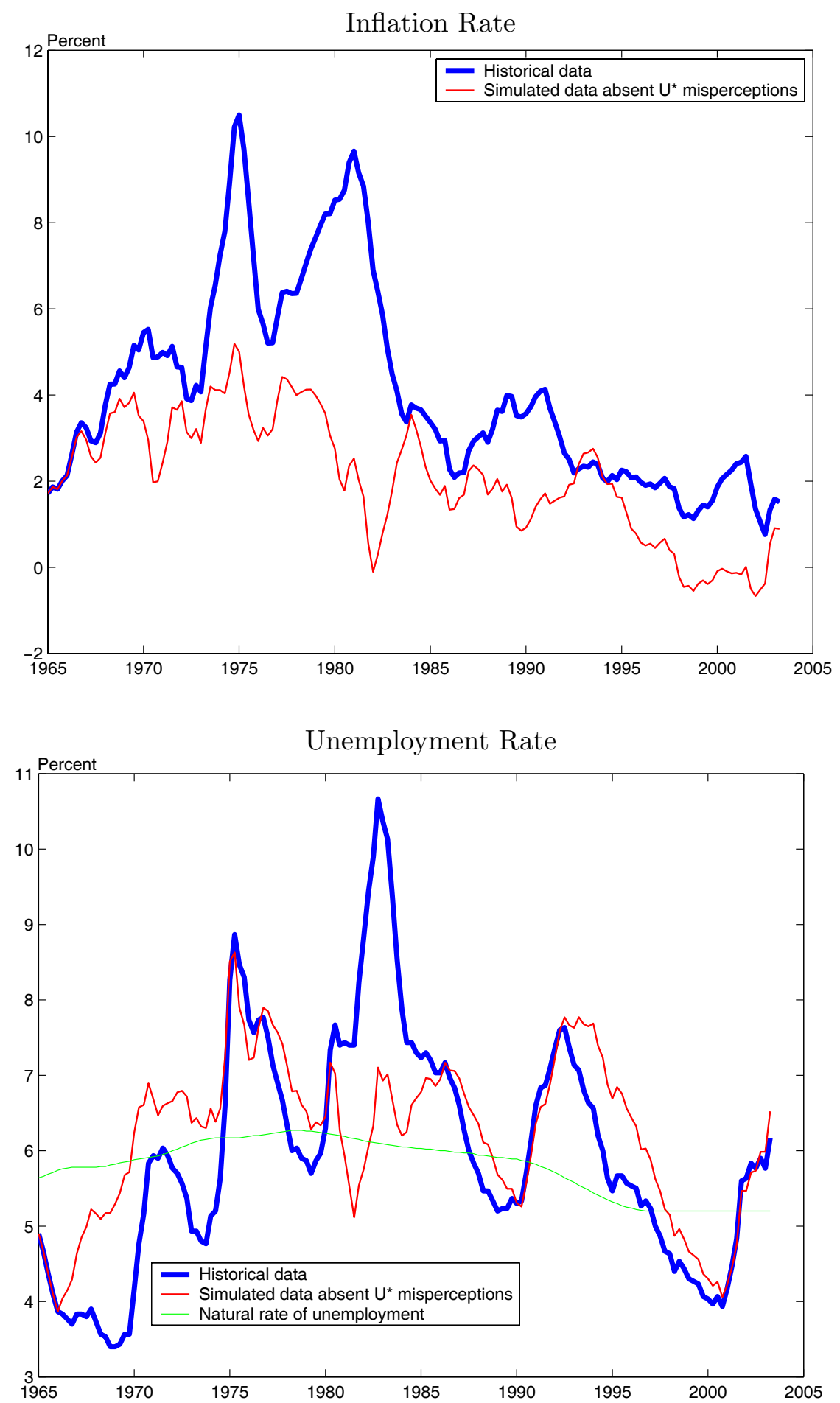

Notes: The two panels show historical and simulated paths of the rates of inflation and unemployment. The thick solid lines show the historical data. The thin solid lines show the simulated paths assuming that the monetary policymaker knows the true value of the natural rate of unemployment in real time. The lightly-shaded thin solid line in the lower panel shows the assumed path for the natural rate of unemployment. Each simulation starts in the first quarter of 1966. 
Figure 5

Evolution of Inflation Persistence in the Inflation Forecasting Equation

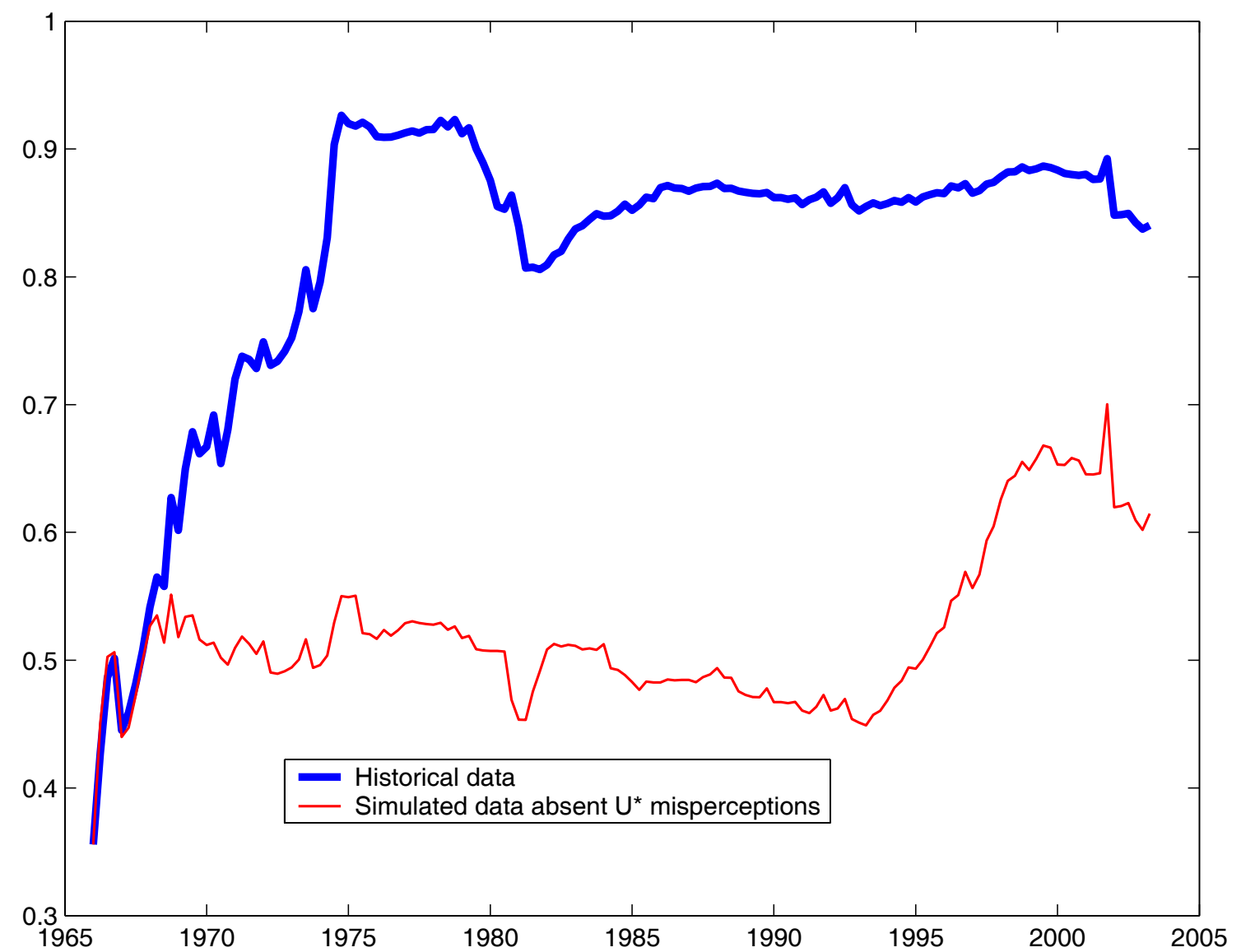

Notes: The lines show the simulated paths of the sum of the coefficients on lagged inflation in agents' inflation forecasting equations. The path shown by the thick line is based on the historical data. The thin line shows the simulated path in which the policymaker knows the true value of the natural rate of unemployment in real time. Each simulation starts in the first quarter of 1966 . 
Figure 6

\section{Outcomes with Fixed-Coefficient Expectations}

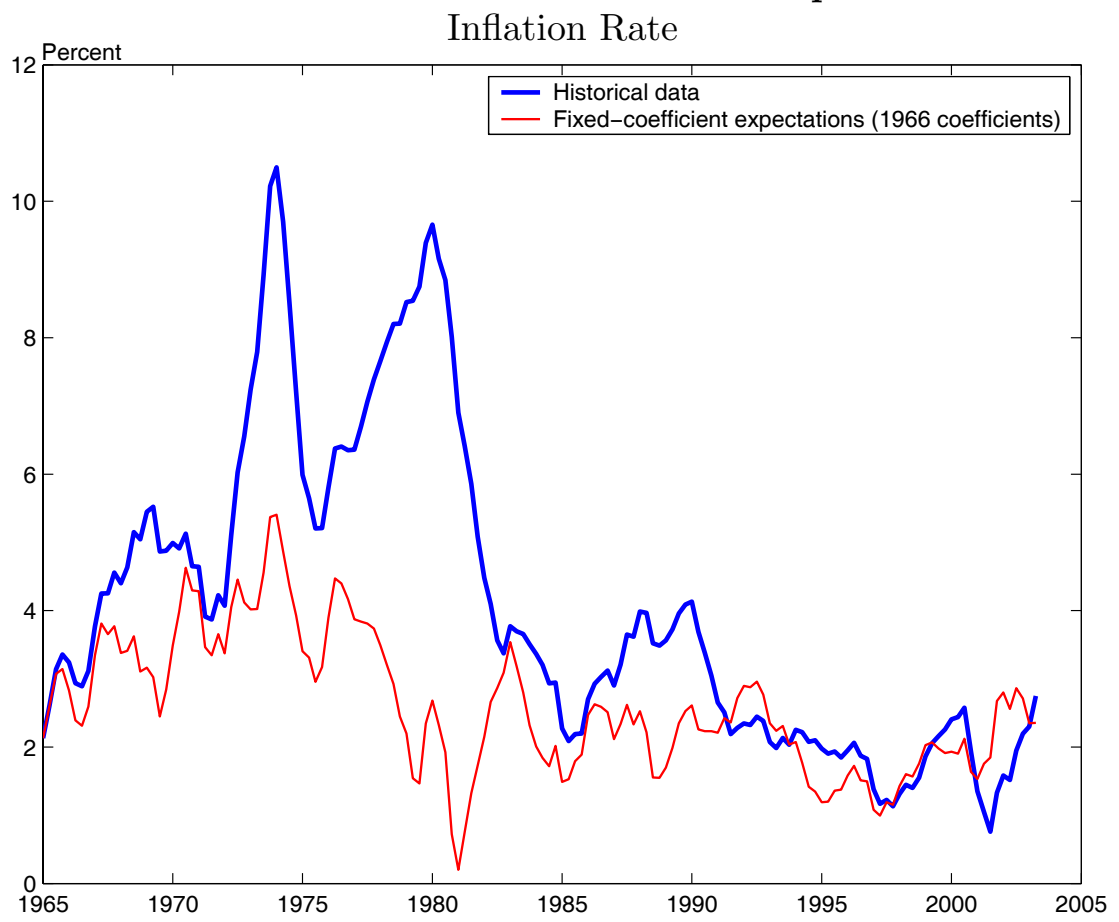

Unemployment Rate

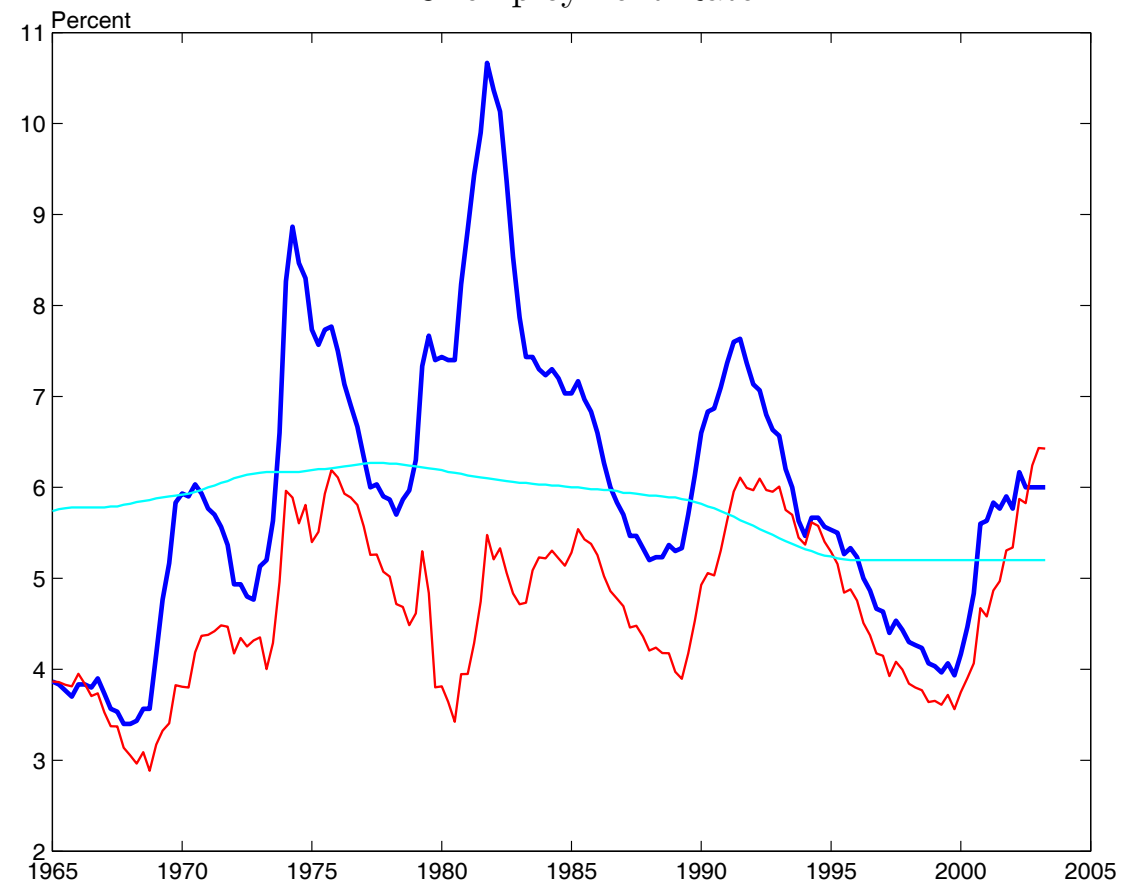

Notes: The two panels show historical and simulated paths of the rates of inflation and unemployment. The thick solid lines show the historical data. The thin solid lines show the simulated paths assuming that the agents do not update their forecasting models from 1966 on. Each simulation starts in the first quarter of 1966. 
Figure 7

\section{Outcomes with Alternative Policy Rules}

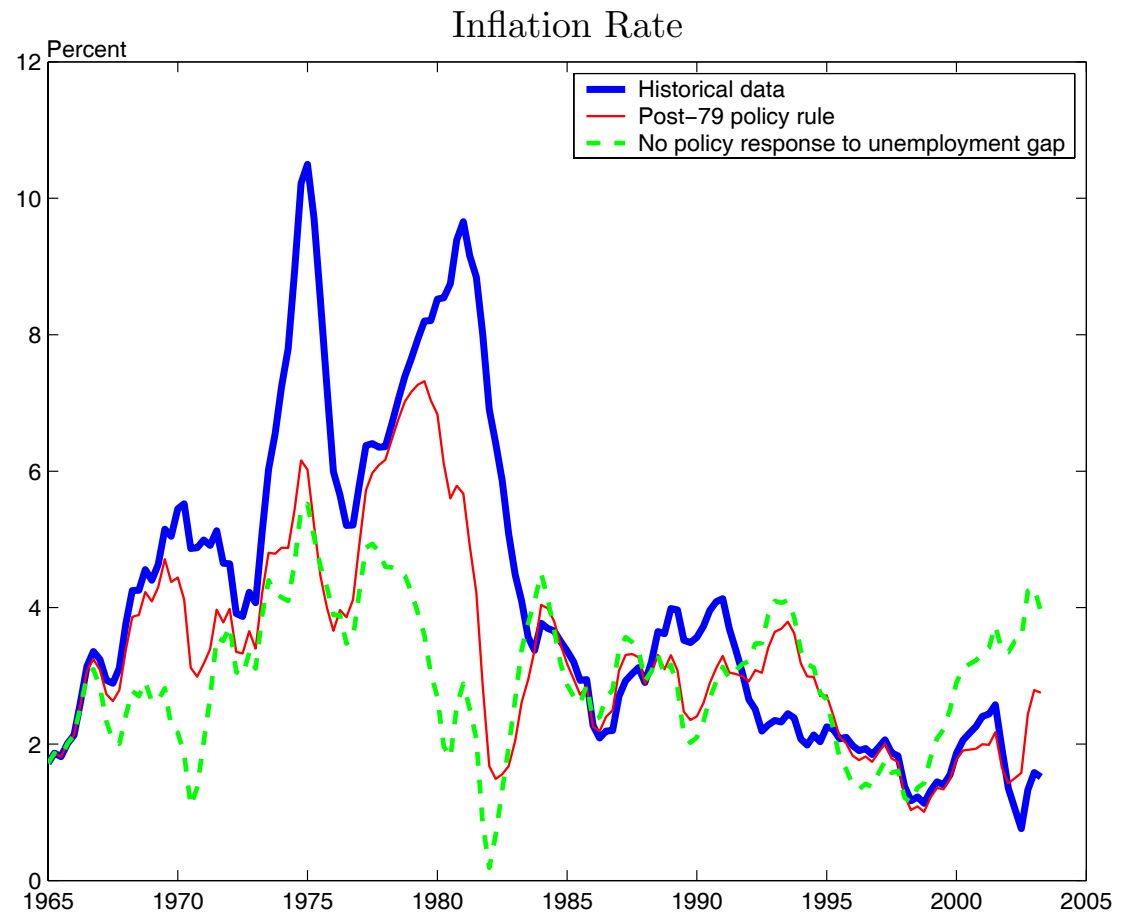

Unemployment Rate

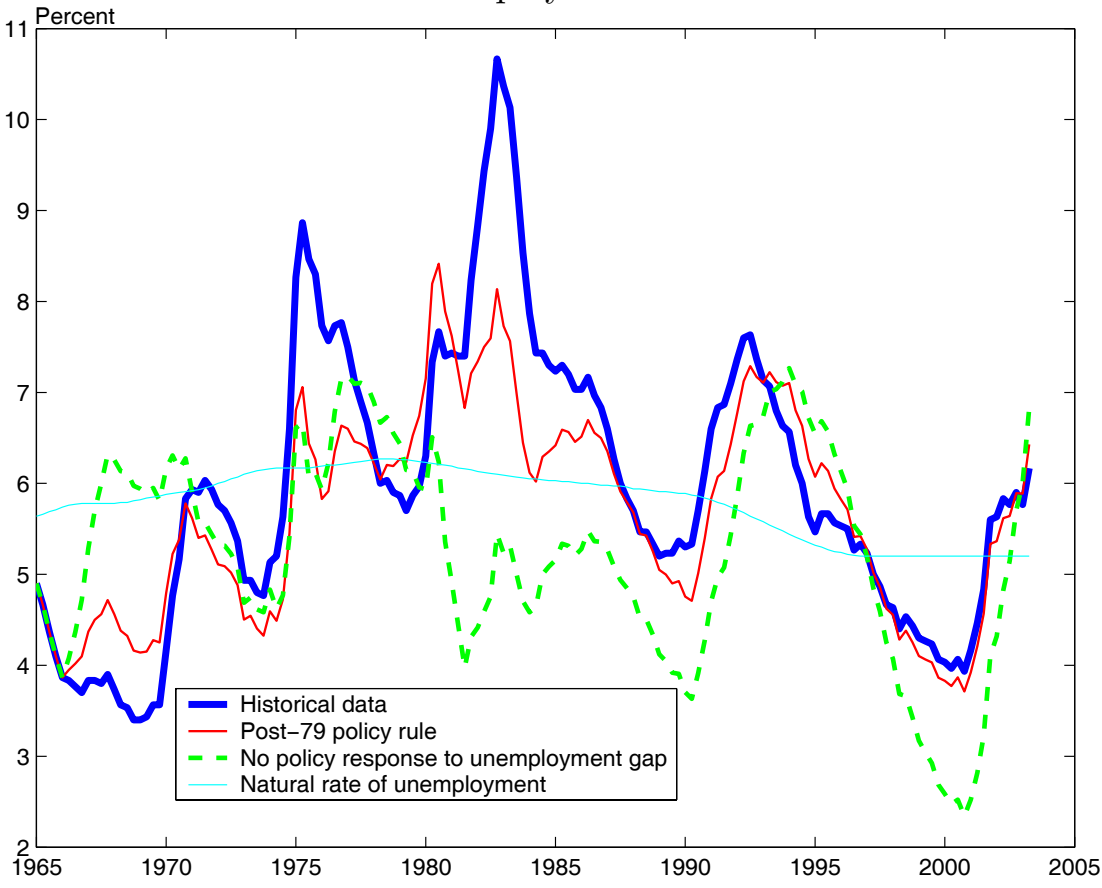

Notes: The two panels show historical and simulated paths of the rates of inflation and the unemployment. The paths shown by the thick solid lines are based on the historical data. The thin solid lines show the simulated paths in which monetary policy follows the post-1979 policy rule. The thick dashed lines show the simulated paths when policy does not respond to the unemployment gap. Each simulation starts in the first quarter of 1966. 
Figure 8

\section{Evolution of Inflation Persistence with Alternative Policy Rules}

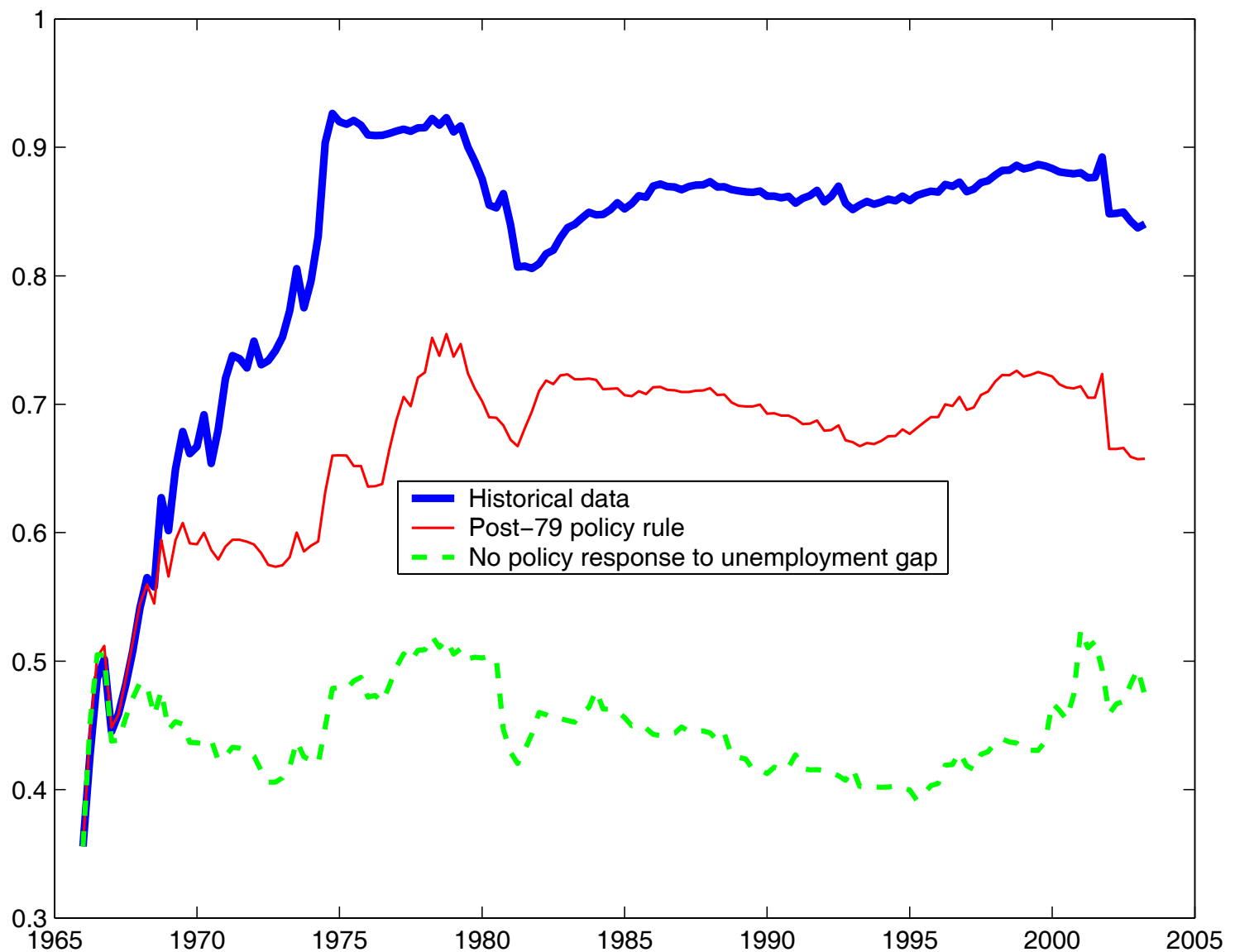

Notes: The lines show the simulated paths of the sum of the coefficients on lagged inflation in agents' inflation forecasting equations. The path shown by the thick solid line is based on the historical data. The thin solid line shows the simulated path in which monetary policy follows the post-1979 policy rule. The thick dashed line shows the simulated path when policy does not respond to the unemployment gap. Each simulation starts in the first quarter of 1966. 